\title{
Latent Enamine Functionality of 5-Methyl-2,3-dihydropyrazines
}

\author{
Shigeru Ito, ${ }^{*, a}$ Tomoya Hirano, ${ }^{a}$ Akiko Sugimoto, ${ }^{a}$ Hiroyuki Kagechika, ${ }^{b}$ Shinji Takechi, ${ }^{c}$ and \\ Tadatoshi $\mathrm{YAMAGUCHI}^{c}$ \\ ${ }^{a}$ Institute of Biomaterials and Bioengineering, Tokyo Medical and Dental University; ${ }^{b}$ Graduate School of Biomedical \\ Science, Tokyo Medical and Dental University; Chiyoda-ku, Tokyo 101-0062, Japan: and ${ }^{c}$ Faculty of Pharmaceutical \\ Science, Sojo University; Kumamoto 860-0082, Japan. \\ Received March 2, 2010; accepted April 19, 2010; published online April 26, 2010
}

\begin{abstract}
Tautomerization of methyl-substituted dihydropyrazine (DHP) derivatives to their latent enamine form was investigated theoretically and empirically. Among two types of hydrogen transfer model simulated by means of density functional theory calculation, a simple intramolecular hydrogen shift mechanism for 5,6-dimethyl-2,3-dihydropyrazine (1) and 5-methyl-6-phenyl-2,3-dihydropyrazine (3) required high activation energies for tautomerism, while a water-assisted intermolecular hydrogen transfer mechanism gave smaller activation energies (about $160 \mathrm{~kJ} / \mathrm{mol}$ ). Examination of the deuterium exchange reaction of 3 in $50 \%(\mathrm{v} / \mathrm{v}) \mathrm{D}_{2} \mathrm{O} /$ dimethyl sulfoxide- $d_{6}$ solution revealed temperature-dependent and stepwise deuterium exchange of the 5-methyl group. Reaction of compound 3 with phenyl isocyanate in acetonitrile afforded a mono adduct (7) at the 5-methyl group, and a cyclic adduct (8). These results represent evidence of tautomerism of 5-methyl-2,3-dihydropyrazines (imine forms) to the latent enamine tautomers, and suggest that DHPs may behave as enamines to a significant degree under physiological conditions.
\end{abstract}

Key words dihydropyrazine; enamine tautomer; theoretical study; deuterium exchange

Dihydropyrazine derivatives (DHPs) derived from dimerization of amino sugars, such as glucosamine and mannosamine, spontaneously generate carbon-centered radicals and exhibit DNA strand-breaking activity, which may be related to the apoptotic activity of amino sugars. ${ }^{1,2)}$ The DHP derivative 3,6-dihydropyrazine-2,5-dipropionic acid is formed by dimerization of 5-aminolevulic acid, which is accumulated in congenital and acquired hepatic porphyrias, such as acute intermittent porphyria, and might induce hepatocellular carcinoma. ${ }^{3)}$ The dimerization of these $\alpha$ aminocarbonyl compounds proceeds via a non-enzymatic process under physiological conditions to afford 2,5-DHPs initially, and these might be isomerized to other types of DHPs as a consequence of resonance stabilization, and/or oxidized to pyrazines. However, the thermal and chemical instability of DHPs has made it difficult to investigate their chemical properties and biological functions in detail.

Previously we reported the preparation of simple DHP derivatives such as 5,6-dimethyl-2,3-DHP (1) and 2,2,5,6tetramethyl-2,3-DHP (2) by the reaction of diacetyl and ethylenediamines in diethyl ether according to Ishiguro's procedure (Chart 1). ${ }^{4}$ These methyl-substituted DHPs showed DNA strand-breaking activity with potency comparable to that of DHP formed from D-glucosamine. ${ }^{5)}$ During mechanistic investigations, we found that compound $\mathbf{2}$ dimerized at room temperature without any catalyst. ${ }^{6,7)}$ Semi-empirical PM3 molecular orbital (MO) calculation suggested the feasibility of tautomerization from 2 (diimine form) to 2 exo (enamine form) during the dimerization reaction. Further, from a biological viewpoint, the reduction of Koopman's ionization potential value $\left(\mathrm{IP}=-E_{\mathrm{HOMO}}\right)$ resulting from tautomerization of DHPs to the enamine form should be closely related to the DNA-damaging ability. ${ }^{8)}$ However, there is no evidence for the formation of an enamine moiety, such as 1 exo and 2exo. In this study, we explored the possible formation of enamine tautomers of DHPs by means of theoretical and empirical methods.

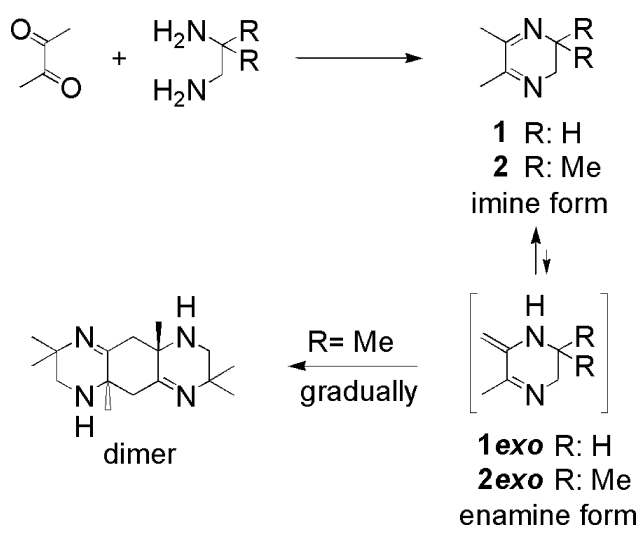

Chart 1

\section{Experimental}

Computation The Spartan '06 and '08 for Windows software ${ }^{9)}$ with the density functional theory (DFT) B3LYP $\mathrm{L}^{10} / 6-311+\mathrm{G}^{* *}$ basis set was employed to estimate the global minimum energy of the optimized structures of compounds and transition states (TS). Zero point energy was not corrected. The obtained TS geometry was evaluated by means of vibrational frequency analysis and intrinsic reaction coordinate (IRC) calculation. The solvation effect of water was approximated by way of the SM8 model ${ }^{11}$ at the DFT B3LYP/6-31G* basis set level, because the SM8 model did not cover 6$311+\mathrm{G}^{* *}$ basis set.

Experimental All chemicals were available in commercial. Phenyl propane-1,2-dione, $\mathrm{N}$-methyl ethylenediamine and phenyl isocyanate were purchased from Tokyo Chemical Industry Co., Ltd., ethylenediamine and acetonitrile were from Kanto Chemical Co., Inc. Deuterium oxide and pyridine- $d_{5}$ were also purchased from CEA, and DMSO- $d_{6}$ was from Isotec Inc. Melting points were measured with Yanagimoto MP-3, and were uncorrected. The NMR experiments were carried out with Bruker AVANCE500 spectrometers at $500 \mathrm{MHz}\left({ }^{1} \mathrm{H}\right)$ and $125 \mathrm{MHz}\left({ }^{13} \mathrm{C}\right)$. The chemical shifts were expressed in $\delta \mathrm{ppm}$. Full assignment was performed with the combination analysis of 2D-nuclear Overhauser effect spectroscopy (NOESY), heteronuclear single quantum coherence (HSQC) and heteronuclear multiple bond connectivity (HMBC) spectra. Mass spectra were taken with JMSSX110 and AX-505 spectrometer. High resolution FAB mass spectra were recorded with 3-nitrobenzylalcohol matrix. IR spectra were recorded with JASCO 6100 FT-IR spectrometer. Elemental analysis was determined by Yanaco MT-6 analyzer. 


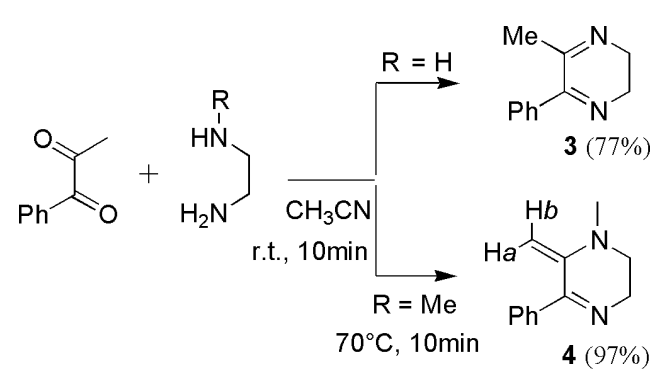

Chart 2

Preparation of 5-Methyl-6-phenyl-2,3-dihydropyrazine (3) A solution of ethylenediamine $(5.5 \mathrm{mmol})$ in acetonitrile $(4 \mathrm{ml})$ was added dropwise to a solution of phenylpropane-1,2-dione $(5 \mathrm{mmol})$ in acetonitrile $(10 \mathrm{ml})$ at room temperature, and the mixture was stirred for $10 \mathrm{~min}$. After removal of solvent in reduced pressure, the residual gum was dissolved in dichloromethane, and was washed with cold water for three times to remove excess ethylenediamine. The organic layer was dried with anhydrous sodium sulfate, and evaporated to afford the dihydropyrazine in almost pure state Recrystallization from $n$-hexane to give yellow granules in a 77\% yield, $\mathrm{mp}$ $36-37^{\circ} \mathrm{C}\left(38-39^{\circ} \mathrm{C},{ }^{12)} 34-37^{\circ} \mathrm{C}^{13,14}\right)$.

1-Methyl-6-methylene-5-phenyl-1,2,3,6-tetrahydropyrazine (4) The reaction according to mentioned above and $\left(70^{\circ} \mathrm{C}, 10 \mathrm{~min}\right)$ to afford 4 (181 mg, 97\%) crude orange oil. Kugel Role distillation of the crude oil at $135-140{ }^{\circ} \mathrm{C} / 0.7$ Torr afforded of 4 as pale yellow oil. ${ }^{1} \mathrm{H}-\mathrm{NMR}\left(\mathrm{CDCl}_{3}\right) \delta$ : $2.78(3 \mathrm{H}, \mathrm{s}), 3.05(2 \mathrm{H}, \mathrm{t}, J=5.6 \mathrm{~Hz}), 3.93(2 \mathrm{H}, \mathrm{t}, J=5.6 \mathrm{~Hz}), 4.16(1 \mathrm{H}, \mathrm{d}$, $J=1.2 \mathrm{~Hz}), 4.36(1 \mathrm{H}, \mathrm{d}, J=1.2 \mathrm{~Hz}), 7.34-7.37(3 \mathrm{H}, \mathrm{m}), 7.45-7.48(2 \mathrm{H}$ m). ${ }^{13} \mathrm{C}$-NMR $\delta: 39.6,47.6,49.6,92.6,127.6,128.4,128.6,139.7,144.4$, 165.8. NOE was observed between $\mathrm{H}-6 \mathrm{a}$ and $\mathrm{H}-6 \mathrm{~b}, \mathrm{H}-6 \mathrm{~b}$ and $1-\mathrm{CH}_{3}, 1-\mathrm{CH}_{3}$ and $\mathrm{H}-2, \mathrm{H}-2$ and H-3. EI-MS $m / z 186\left(\mathrm{M}^{+}\right), 185$ (Bp), 143. Anal. Calcd for $\mathrm{C}_{12} \mathrm{H}_{14} \mathrm{~N}_{2}$ : C, 77.38, H, 7.58, N, 15.04. Found: C, 77.11, H, 7.68, N, 14.92.

2-Methyl-3-phenylpyrazine A mixture of ethylenediamine $(1 \mathrm{ml})$ and phenylpropane-1,2-dione $(1 \mathrm{mmol})$ was heated at $100^{\circ} \mathrm{C}$ for $2.5 \mathrm{~h}$. Excess ethylenediamine was evaporated off in reduced pressure, and the residue was poured into ice, extracted with dichloromethane for three times. The combined organic layer was washed with cold water, and dried with anhydrous sodium sulfate. After evaporation, the residue was purified by silica gel column chromatography ( $30 \%$ diethyl ether $/ n$-hexane) to afford colorless oil. Kugel Role distillation at $205^{\circ} \mathrm{C} / 2$ Torr $\left(158-160^{\circ} \mathrm{C} / 22\right.$ Torr, ${ }^{15)} 140^{\circ} \mathrm{C} / 7$ Torr ${ }^{16)}$ ) afforded $102 \mathrm{mg}(65 \%)$ of 2-methyl-3-phenylpyrazine as colorless oil, which solidified in $-20{ }^{\circ} \mathrm{C}$ freezer, mp $31-32^{\circ} \mathrm{C} .{ }^{1} \mathrm{H}-\mathrm{NMR}^{15,17}$ $\left(\mathrm{CDCl}_{3}\right) \delta: 2.65(3 \mathrm{H}, \mathrm{s}), 7.43-7.51(3 \mathrm{H}, \mathrm{m}), 7.57-7.60(2 \mathrm{H}, \mathrm{dd}, J=8.5$, $1.9 \mathrm{~Hz}), 8.45(1 \mathrm{H}, \mathrm{d}, J=2.5 \mathrm{~Hz}), 8.49(1 \mathrm{H}, \mathrm{d}, J=2.5 \mathrm{~Hz})$.

Reaction of 4 with Phenyl Isocyanate Phenyl isocyanate $(60 \mathrm{mg})$ was added to a solution of $4(47 \mathrm{mg})$ in acetonitrile $(1 \mathrm{ml})$ at room temperature, and the reddish solution was stirred at room temperature for $1 \mathrm{~h}$. After removal of solvent in reduced pressure, the residue was purified by silica gel column chromatography (ethyl acetate, $R f 0.12$ ) to give $\mathbf{5}$ as a colorless solid (47 mg, 61\%). Recrystallization from methanol afforded colorless powder, $\mathrm{mp} 234-235^{\circ} \mathrm{C} .{ }^{1} \mathrm{H}-\mathrm{NMR}\left(\mathrm{CDCl}_{3}\right) \delta: 2.17(1 \mathrm{H}, \mathrm{brs}), 2.86(3 \mathrm{H}, \mathrm{s}), 2.89$ $(2 \mathrm{H}, \mathrm{m}), 3.00(1 \mathrm{H}, \mathrm{dt}, J=13.2,6.1 \mathrm{~Hz}), 3.12(1 \mathrm{H}, \mathrm{dt}, J=13.2,6.1 \mathrm{~Hz}), 5.08$ $(1 \mathrm{H}, \mathrm{s}), 7.01-7.19(8 \mathrm{H}, \mathrm{m}), 7.29-7.32(2 \mathrm{H}, \mathrm{m}) .{ }^{13} \mathrm{C}-\mathrm{NMR} \delta: 39.6,39.7$ $49.3,79.3,89.2,126.0,126.3,127.8,128.1,128.2,136.4,137.4,167.1$, 171.9. IR $\left(\mathrm{KBr}, \mathrm{cm}^{-1}\right) 1673,1628,1329$. Anal. Calcd for $\mathrm{C}_{19} \mathrm{H}_{19} \mathrm{~N}_{3} \mathrm{O}: \mathrm{C}$, 74.73, H, 6.27, N, 13.76. Found: C, 75.01, H, 6.49, N, 13.76.

Reaction of 5 with Phenyl Isocyanate A mixture of $5(12 \mathrm{mg})$ and phenyl isocyanate $(60 \mathrm{mg})$ was stirred for $2 \mathrm{~h}$ at room temperature, and the mixture was purified by silica gel column chromatographic (5\% ethyl acetate/dichloromethane, then ethyl acetate, $R f(0.5)$ to afford $\mathbf{6}$ as colorless solid $(16 \mathrm{mg}, 96 \%)$. Recrystallization from acetone to afford $12 \mathrm{mg}$ of colorless prisms of $6, \mathrm{mp} 214-215.5^{\circ} \mathrm{C} .{ }^{1} \mathrm{H}-\mathrm{NMR}$ (DMSO- $\left.d_{6}\right) \delta: 2.86(3 \mathrm{H}, \mathrm{s})$, $2.96(1 \mathrm{H}, \mathrm{dt}, J=12.6,5.4 \mathrm{~Hz}), 3.12(1 \mathrm{H}$, ddd, $J=12.6,7.6,6.0 \mathrm{~Hz}), 3.52$ $(1 \mathrm{H}, \mathrm{ddd}, J=14.2,7.7,5.3 \mathrm{~Hz}), 3.89(1 \mathrm{H}, \mathrm{td}, J=14.2,5.4 \mathrm{~Hz}), 5.16(1 \mathrm{H}, \mathrm{s})$, $6.89(2 \mathrm{H}, \mathrm{dd}, J=8.6,1.2 \mathrm{~Hz}), 6.99(1 \mathrm{H}, \mathrm{dt}, J=7.3,1.0 \mathrm{~Hz}), 7.02(1 \mathrm{H}, \mathrm{dt}$ $J=7.3,1.1 \mathrm{~Hz}), 7.12(2 \mathrm{H}, \mathrm{dt}, J=7.7,1.8 \mathrm{~Hz}), 7.20-7.28(5 \mathrm{H}, \mathrm{m}), 7.33(2 \mathrm{H}$, dd, $J=8.5,1.6 \mathrm{~Hz}), 7.42(2 \mathrm{H}, \mathrm{dd}, J=8.7,1.1 \mathrm{~Hz}), 9.49(1 \mathrm{H}, \mathrm{s}) .{ }^{13} \mathrm{C}-\mathrm{NMR} \delta$ $39.6,46.2,48.0,80.7,90.1,119.3,123.0,125.9,126.3,127.4128 .5,128.7$, 128.7, 129.2, 137.7, 138.9, 140.0, 157.2, 165.9, 171.3. IR (KBr, cm $\left.{ }^{-1}\right) 1685$, 1673, 1630. EI-MS $m / z 424\left(\mathrm{M}^{+}\right), 332,305$. Anal. Calcd for $\mathrm{C}_{26} \mathrm{H}_{24} \mathrm{~N}_{4} \mathrm{O}_{2}$ : C, 73.56, H, 5.70, N, 13.20. Found: C, 73.68, H, 5.91, N, 13.01 .

Reaction of 3 with Phenyl Isocyanate A solution of phenyl isocyanate
$(70 \mathrm{mg})$ in acetonitrile $(1 \mathrm{ml})$ was added to a stirring solution of $\mathbf{3}(86 \mathrm{mg})$ in acetonitrile $(1 \mathrm{ml})$, and the mixture was heated at $70^{\circ} \mathrm{C}$ for $7 \mathrm{~h}$. After removal of solvent in reduced pressure, residue was purified by silica gel column chromatography (ethyl acetate) to give $\mathbf{8}(R f 0.66)$ as colorless solid ( $40 \mathrm{mg}, 20 \%$ ) and 7 (Rf 0.52$)$ as yellow solid $(40 \mathrm{mg}, 28 \%)$.

Compound 7: Recrystallization from diethyl ether $/ n$-hexane to afford yellow granules, mp $171.5-172{ }^{\circ} \mathrm{C} .{ }^{1} \mathrm{H}-\mathrm{NMR}\left(\mathrm{CDCl}_{3}\right) \delta: 3.26(2 \mathrm{H}, \mathrm{m}), 3.86$ $(2 \mathrm{H}, \mathrm{t}), 4.58(1 \mathrm{H}, \mathrm{s}), 7.02(1 \mathrm{H}, \mathrm{t}), 7.03(1 \mathrm{H}, \mathrm{br} \mathrm{s}), 7.25(2 \mathrm{H}, \mathrm{t}), 7.36-7.43$ $(5 \mathrm{H}, \mathrm{m}), 7.55(2 \mathrm{H}, \mathrm{m}), 9.11(1 \mathrm{H}, \mathrm{s}) .{ }^{13} \mathrm{C}-\mathrm{NMR} \delta: 36.1,38.6,90.2,119.5$, $123.4,128.0,128.7,128.8,129.6,137.5,138.5,145.5,165.2,168.8$. IR $\left(\mathrm{KBr}, \mathrm{cm}^{-1}\right)$ 3314, 1644, 1583, 1310. EI-MS m/z $291\left(\mathrm{M}^{+}\right), 289,199$ $\left(\mathrm{M}^{+}-\mathrm{PhNH}\right), 170\left(\mathrm{M}^{+}-\mathrm{PhNHCOH}\right)$. Anal. Calcd for $\mathrm{C}_{18} \mathrm{H}_{17} \mathrm{~N}_{3} \mathrm{O}: \mathrm{C}$, 74.20, H, 5.88, N, 14.42. Found: C, 74.29, H, 6.11, N, 14.34 .

Compound 8: Recrystallization from methanol afforded colorless leaflet, mp $236-236.5^{\circ} \mathrm{C} .{ }^{1} \mathrm{H}-\mathrm{NMR}\left(\mathrm{CDCl}_{3}\right) \delta: 2.23(1 \mathrm{H}, \mathrm{t}, J=7.3 \mathrm{~Hz}), 2.67(1 \mathrm{H}$, m), 2.92-3.07 $(2 \mathrm{H}, \mathrm{m}), 3.16(1 \mathrm{H}, \mathrm{m}), 7.05(1 \mathrm{H}, \mathrm{t}, J=13.2,6.1 \mathrm{~Hz}), 7.09-$ $7.14(3 \mathrm{H}, \mathrm{m}), 7.16-7.24(5 \mathrm{H}, \mathrm{m}), 7.30(2 \mathrm{H}, \mathrm{t}), 7.36(2 \mathrm{H}, \mathrm{m}), 7.63(2 \mathrm{H}, \mathrm{m})$, $8.30(1 \mathrm{H}, \mathrm{d}, J=4.3 \mathrm{~Hz}), 10.09(1 \mathrm{H}, \mathrm{s}) .{ }^{13} \mathrm{C}-\mathrm{NMR} \delta: 37.4,38.6,77.9,90.2$, $111.7,123.3,126.4,126.6,127.7,128.5,128.6,128.8,129.1,134.5,135.5$, 138.5, 164.0, 170.1, 171.0. IR( $\left.\mathrm{KBr}, \mathrm{cm}^{-1}\right)$ 1673, 1628. EI ${ }^{+}$-HR-MS $\mathrm{m} / \mathrm{z}$ 411.1829 (Calcd for $\mathrm{C}_{25} \mathrm{H}_{22} \mathrm{~N}_{4} \mathrm{O}_{2}: 411.1821$ ). Anal. Calcd for $\mathrm{C}_{25} \mathrm{H}_{22} \mathrm{~N}_{4} \mathrm{O}_{2}$ : C, 73.15, H, 5.40, N, 13.65. Found: C, 73.41, H, 5.68, N, 13.65 .

Deuterium Exchange Experiment All experiments were carried out in $20 \mathrm{~mm}$ concentration solutions of $\mathbf{3}, \mathbf{4}$ or 2-methyl-3-phenylpyrazine in $50 \%$ $(\mathrm{v} / \mathrm{v}) \mathrm{D}_{2} \mathrm{O} / \mathrm{DMSO}-d_{6}$ or $50 \%(\mathrm{v} / \mathrm{v}) \mathrm{D}_{2} \mathrm{O} /$ pyridine- $d_{5}$, and were prepared under ice-water cooling. Each sample was kept in freezer $\left(-4^{\circ} \mathrm{C}\right)$, at room temperature $\left(23^{\circ} \mathrm{C}\right)$, and HPLC column oven kept at $37^{\circ} \mathrm{C}$ and $65^{\circ} \mathrm{C}$, respectively. ${ }^{1} \mathrm{H}$ - and ${ }^{13} \mathrm{C}-\mathrm{NMR}$ spectra of each sample were measured without defining an interval. Change of integral value of the 5-methyl group and that of the combined 2,3-ethylene part of DHPs in each sample was calibrated on the basis of the integral value of the residual proton signal of DMSO- $d_{6}$ in the solutions, respectively.

\section{Results and Discussion}

Simulation of Tautomerism of DHP In this study we focused on two DHP derivatives $\mathbf{1}$, and unsymmetrical 3 . First, we considered the intramolecular hydrogen shift model. The relative energies based on the DHP form and the imaginary frequencies of the TS are summarized in Table 1. The fully optimized structures of the tautomers and the geometry of the TS for compound $\mathbf{3}$ at the DFT B3LYP/6$311+\mathrm{G}^{* * / / B} 3 \mathrm{LYP} / 6-311+\mathrm{G}^{* *}$ basis set are illustrated in Fig. 1. The geometry of the DHP skeleton in $\mathbf{1}$ and $\mathbf{3}$, the enamine forms, and even the TSs are closely similar to each other. Animation based on vibrational frequency analysis indicated hyperconjugative transfer of the hydrogen atom between the 5-methyl group and nitrogen at the 4-position of $\mathbf{1}$ and 3. In each case, the global minimum energy of the imine

Table 1. Summary of Energy Profile of Intramolecular Hydrogen Shift Model

\begin{tabular}{|c|c|c|c|}
\hline & imine form & $\left.\mathrm{N}_{\mathrm{N}}\right]^{\mathrm{H}} \neq$ & $\begin{array}{l}\mathrm{H} \\
\mathrm{N} \\
\mathrm{N}^{\prime} \\
\text { ne form }\end{array}$ \\
\hline & $\begin{array}{l}\Delta E_{\mathrm{Ts} \text {-imine }} \\
\mathrm{kJ} / \mathrm{mol}\end{array}$ & $\begin{array}{c}\Delta E_{\text {enamine-imine }} \\
\mathrm{kJ} / \mathrm{mol}\end{array}$ & $\begin{array}{c}\text { Imaginary frequency } \\
\text { at } \mathrm{TS}\left(\mathrm{cm}^{-1}\right)\end{array}$ \\
\hline \multirow[t]{3}{*}{ 1: $\mathrm{R}=\mathrm{Me}$} & $271^{a)}$ & $14^{a)}$ & $-1955^{a)}$ \\
\hline & $285^{b)}$ & $27^{b)}$ & $-1969^{b)}$ \\
\hline & $293^{c)}$ & $35^{c)}$ & $-2002^{c)}$ \\
\hline \multirow[t]{3}{*}{ 3: $\mathrm{R}=\mathrm{Ph}$} & $264^{a)}$ & $15^{a)}$ & $-1953^{a)}$ \\
\hline & $276^{b)}$ & $28^{b)}$ & $-1966^{b)}$ \\
\hline & $281^{c)}$ & $34^{c)}$ & $-1999^{c)}$ \\
\hline
\end{tabular}

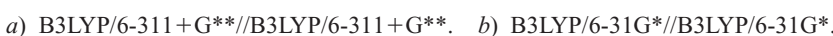
c) B3LYP/6-31G*//B3LYP/6-31G* with aqueous solvation effect by SM8. 


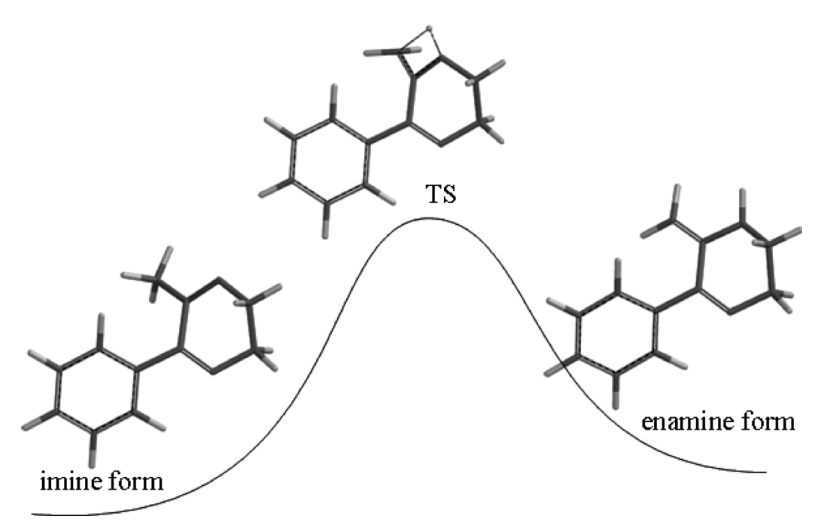

Fig. 1. Intramolecular Hydrogen Shift Model for Tautomerism of $\mathbf{3}$

form was lower than that of the corresponding enamine tautomer in gas phase.

The TS barriers for 1 and 3 turned out to be $271 \mathrm{~kJ} / \mathrm{mol}$ and $264 \mathrm{~kJ} / \mathrm{mol}$ at the B3LYP/6-311+G** level and 285 $\mathrm{kJ} / \mathrm{mol}$ and $276 \mathrm{~kJ} / \mathrm{mol}$ at the $\mathrm{B} 3 \mathrm{LYP} / 6-31 \mathrm{G}^{*}$ level, respectively. The solvation effect of aqueous medium increased the relative energy gap between the two tautomers $(35 \mathrm{~kJ} / \mathrm{mol}$ for $\mathbf{1}$ and $34 \mathrm{~kJ} / \mathrm{mol}$ for $\mathbf{3}$ ), and also increased the TS barrier to $293 \mathrm{~kJ} / \mathrm{mol}$ for $\mathbf{1}$ and $281 \mathrm{~kJ} / \mathrm{mol}$ for 3 in our model at the B3LYP/6-31G* level. A theoretical study on the analogue energy profile of $\mathrm{CH}_{3} \mathrm{C}(\mathrm{X})=\mathrm{NH}$ (imine) and $\mathrm{CH}_{2}=\mathrm{CXNH}_{2}$ (enamine) tautomerism by Pérez and Toro-Labbé using DFT B3LYP/6-311G** calculation in the gas phase showed that the imine form has a lower energy by at least $16 \mathrm{~kJ} / \mathrm{mol} \mathrm{com-}$ pared with the enamine counterpart in every case examined, and the values of the energy barrier $\left(\Delta E=E_{\mathrm{TS}}-E_{\text {imine }}\right)$ were estimated to be $280 \mathrm{~kJ} / \mathrm{mol}(\mathrm{X}=\mathrm{H})$ and $274 \mathrm{~kJ} / \mathrm{mol}$ $\left(\mathrm{X}=\mathrm{CH}_{3}\right) .{ }^{18)}$ Their results are in good agreement with ours for the DHPs. In view of the rather high calculated energy barrier of tautomerization, a simple intramolecular hydrogen shift model seems unlikely.

Many authors have proposed the involvement of protic solvents in the hydrogen transfer mechanism of keto-enol tautomerism. ${ }^{19)}$ Therefore, we next considered a water molecule-assisted intermolecular hydrogen transfer mechanism. The fully optimized structures of $\mathbf{1}, \mathbf{3}$ and their tautomers, and the corresponding TSs associated with a water molecule in the gas phase are illustrated in Fig. 2. The relative energy values and the imaginary frequencies at the TS are summarized in Table 2. In this model, animation based on imaginary frequency analysis showed simultaneous intermolecular hydrogen transfer between one hydrogen atom of the 5-methyl group and the oxygen atom of water, and between one hydrogen atom of water and nitrogen at the 4-position of $\mathbf{1}$ and $\mathbf{3}$. In this model too, the energies of the imine forms were lower than those of the corresponding enamine tautomers, and the relative energy gaps $(26 \mathrm{~kJ} / \mathrm{mol}$ and $40 \mathrm{~kJ} / \mathrm{mol}$ at the B3LYP/6-311+ G**//B3LYP/6-311+ $\mathrm{G}^{* *}$ and B3LYP/6-31$\mathrm{G}^{*} / / \mathrm{B} 3 \mathrm{LYP} / 6-31 \mathrm{G}^{*}$ level, respectively) were greater than in the first model. The activation energy barrier to the TS is markedly reduced to $158 \mathrm{~kJ} / \mathrm{mol}$ for $\mathbf{1}$ and $161 \mathrm{~kJ} / \mathrm{mol}$ for 3 at the B3LYP/6-311+ $\mathrm{G}^{* *}$ level, possibly due to stabilization by formation of a pseudo-six-membered hydrogen bonding network.

Thus, DFT MO calculation showed that a simple intramol-

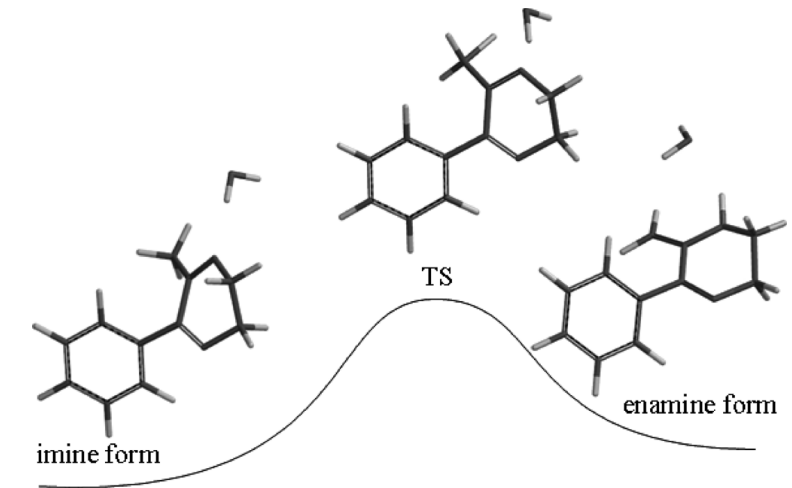

Fig. 2. Water-Assisted Intermolecular Hydrogen Transfer Model of $\mathbf{3}$

Table 2. Summary of Energy Profile of the Water-Assisted Hydrogen Transfer Model

\begin{tabular}{|c|c|c|c|}
\hline & imine form & 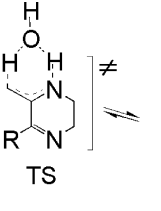 & enamine form \\
\hline & $\begin{array}{c}\Delta E_{\mathrm{Ts} \text {-imine }} \\
\mathrm{kJ} / \mathrm{mol}\end{array}$ & $\begin{array}{c}\Delta E_{\text {enamine-imine }} \\
\mathrm{kJ} / \mathrm{mol}\end{array}$ & $\begin{array}{c}\text { Imaginary frequency } \\
\text { at } \mathrm{TS}\left(\mathrm{cm}^{-1}\right)\end{array}$ \\
\hline 1: $\mathrm{R}=\mathrm{Me}$ & $\begin{array}{l}158^{a)} \\
161^{b)}\end{array}$ & $\begin{array}{l}26^{a)} \\
40^{b)}\end{array}$ & $\begin{array}{l}-1320^{a)} \\
-1457^{b)}\end{array}$ \\
\hline 3: $\mathrm{R}=\mathrm{Ph}$ & $\begin{array}{l}161^{a)} \\
160^{b)}\end{array}$ & $\begin{array}{l}23^{a)} \\
39^{b)}\end{array}$ & $\begin{array}{l}-1377^{a)} \\
-1471^{b)}\end{array}$ \\
\hline
\end{tabular}

a) $\mathrm{B} 3 \mathrm{LYP} / 6-311+\mathrm{G}^{* *} / / \mathrm{B} 3 \mathrm{LYP} / 6-311+\mathrm{G}^{* *}$. b) B3LYP/6-31G*//B3LYP/6-31G*.

ecular hydrogen shift model of the tautomerization process of DHPs requires comparatively high energy, while a waterassisted intermolecular hydrogen transfer mechanism is markedly preferable in terms of energy, perhaps allowing the tautomerization to occur at physiological temperature.

Chemistry In order to confirm the tautomerization of DHPs, we selected 5-methyl-6-phenyl-DHP derivatives (3), since the calculation results showed the similarity of $\mathbf{1}$ and $\mathbf{3}$ in structure and properties during tautomerization and the analysis would be simplified by the involvement of only a single set of imine and enamine forms. The $N$-methylated derivative $\mathbf{4}$ was also prepared for comparison.

Deuterium Exchange Gollnick et al. reported that no deuterium exchange was observed when 5-methyl-6-(4methylphenyl)-2,3-dihydropyrazine was treated in deoxygenated $50 \%(\mathrm{v} / \mathrm{v}) \mathrm{CH}_{3} \mathrm{CN} / \mathrm{CD}_{3} \mathrm{OD}$ in the dark or in the presence of rose bengal under light for several hours. ${ }^{12)}$ On the other hand, there are several reports of deuterium exchange at the $\alpha$-position of imines in $\mathrm{CD}_{3} \mathrm{OD}^{20,21)}$

Considering the favorable calculation results of the waterassisted model, deuterium exchange of $\mathbf{3}$ in $50 \%(\mathrm{v} / \mathrm{v})$ $\mathrm{D}_{2} \mathrm{O} / \mathrm{DMSO}-d_{6}$ solution $(20 \mathrm{~mm})$ at $23{ }^{\circ} \mathrm{C}, 37^{\circ} \mathrm{C}$, and $65^{\circ} \mathrm{C}$ was examined (Chart 3). The time-dependent ${ }^{1} \mathrm{H}-\mathrm{NMR}$ spectral change of the methyl proton signal at $\delta 1.91 \mathrm{ppm}$ at $65^{\circ} \mathrm{C}$ is shown in Fig. 3. After several hours, a new broad triplet-like signal appeared at $8 \mathrm{~Hz}$ higher field from the 5methyl signal, as shown in Fig. 3b, and its intensity increased as the integral value of the 5-methyl group gradually decreased. Another new signal appeared at a further $8 \mathrm{~Hz}$ 


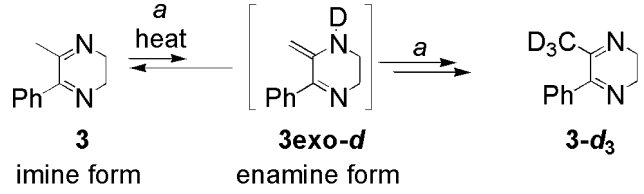

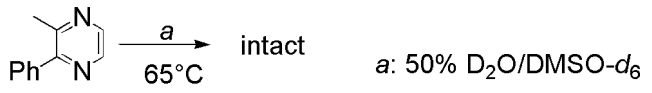

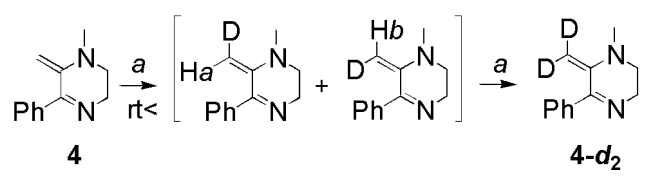

Chart 3

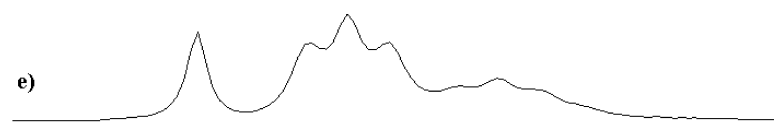

d)

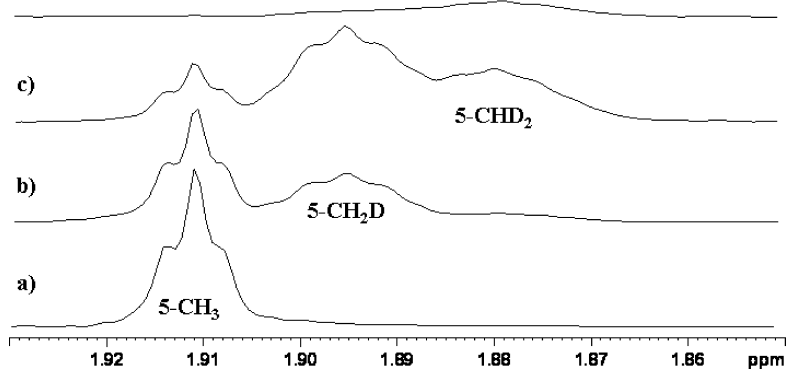

Fig. 3. ${ }^{1} \mathrm{H}-\mathrm{NMR}$ Spectral Change of $\mathbf{3}$ in $50 \% \mathrm{D}_{2} \mathrm{O} / \mathrm{DMSO}-d_{6}$ at $65^{\circ} \mathrm{C}$

a) Original, b) $21 \mathrm{~h}$, c) $42 \mathrm{~h}$, d) $72 \mathrm{~h}$, e) homo-spin decoupling spectrum of c) irradiated at $\delta 3.35 \mathrm{ppm}$.

higher field after $25 \mathrm{~h}$. These three signals (triplet, broad triplet-like, and broad signals, from lower field, Fig. 3c) became singlet, triplet $(J=1.9 \mathrm{~Hz})$ and quintet $(J=1.9 \mathrm{~Hz})$, respectively, in the homo-spin decoupling spectrum upon irradiation of the geminal protons at the 3-position (Fig. 3e). The residual solvent peak in DMSO- $d_{6}$ appeared as a quintet of $\left.{ }^{2} J \mathrm{D} / \mathrm{H}=1.9 \mathrm{~Hz}^{22}\right)$ These time-dependent changes of height and shape of the new signals in the ${ }^{1} \mathrm{H}-\mathrm{NMR}$ spectra indicated that stepwise deuterium exchange proceeded at the 5methyl group of $\mathbf{3}$, and the residual protons, $5-\mathrm{CH}_{2} \mathrm{D}$ and 5$\mathrm{CHD}_{2}$, were observed successively at $8 \mathrm{~Hz}$ higher field owing to the deuterium isotope effect. Further, the sample after the NMR study (72 h) afforded a molecular ion peak of $\mathrm{m} / \mathrm{z} 175$, an increase of 3 mass units from that of $3\left(\mathrm{C}_{11} \mathrm{H}_{12} \mathrm{~N}_{2}\right.$ : mw 172), in the EI mass spectrum. After $72 \mathrm{~h}$ at $65^{\circ} \mathrm{C}$, the ${ }^{1} \mathrm{H}$ NMR spectrum (Fig. 3d) did not show any clear signals except for the very slight upheaval of the base line around $\delta$ $1.9 \mathrm{ppm}$, i.e., trideuterated $\mathbf{3}\left(\mathbf{3}-d_{3}\right.$, Chart 3$)$ had been formed. As shown in Fig. 4, the combined integral value corresponding to ethylene protons (2, 3 positions) of the DHP ring slowly decreased, although these protons were not exchanged with deuterium. The appearance of many small signals suggested that partial decomposition of $\mathbf{3}$ occurred during deuterium exchange reaction at $65^{\circ} \mathrm{C}$. Therefore, the half-life of the combined integral values of 5-methyl-derived signals was about 26 to $27 \mathrm{~h}$ when considering of partial decomposition.

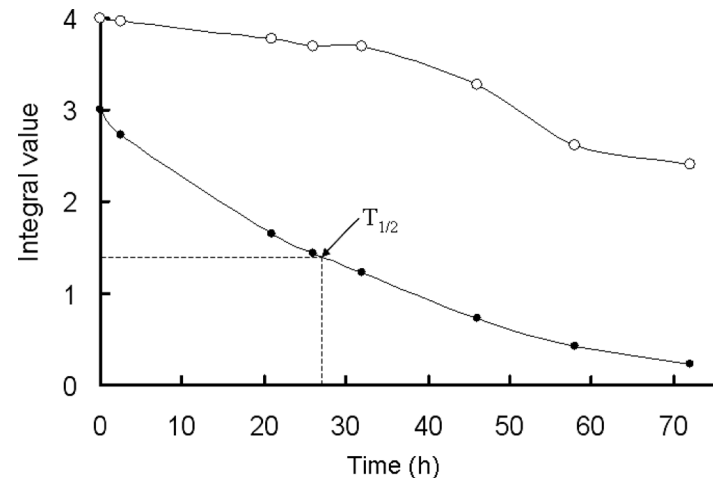

Fig. 4. Time-Dependent Change of Integral Value of the 5-Methyl Group (Closed Circle) and the Combined Ethylene Moiety at the 2, 3 Positions (Open Circle) of 3 at $65^{\circ} \mathrm{C}$ in $50 \% \mathrm{D}_{2} \mathrm{O} / \mathrm{DMSO}-d_{6}$.

As reported by Gollnick et al. ${ }^{12)}$ the deuterium exchange of 3 did not occur in $50 \%(\mathrm{v} / \mathrm{v}) \mathrm{D}_{2} \mathrm{O} / \mathrm{DMSO}-d_{6}$ at room temperature, while about $20 \%$ deuterium exchange was observed after $72 \mathrm{~h}$ at $37^{\circ} \mathrm{C}$. In contrast with 3, 2-methyl-3-phenylpyrazine remained intact during treatment at $65^{\circ} \mathrm{C}$ in $50 \%$ (v/v) $\mathrm{D}_{2} \mathrm{O} / \mathrm{DMSO}-d_{6}$ for $3 \mathrm{~d}$ (Chart 3 ).

Based on the results of deuterium exchange between tertiary enamines and acetone- $d_{6}$ in the absence of catalyst ${ }^{23)}$ we synthesized the $\mathrm{N}$-methylated derivative $\mathbf{4}$ and treated it in $50 \%(\mathrm{v} / \mathrm{v}) \mathrm{D}_{2} \mathrm{O} / \mathrm{DMSO}-d_{6}$ as described for 3 (Chart 3). The ${ }^{1} \mathrm{H}-\mathrm{NMR}$ spectrum of $4 \mathrm{kept}$ at $37^{\circ} \mathrm{C}$ for $7 \mathrm{~h}$ showed clear changes (Fig. 5). The singlet signal of the methyl group on the nitrogen atom $(\delta 2.6 \mathrm{ppm})$ was divided into two broad peaks $(\Delta=1.6 \mathrm{~Hz}$, not a doublet), and the triplet signal of 2methylene protons $(\delta 2.9 \mathrm{ppm})$ was changed to overlapping triple triplets $(\Delta=1.0 \mathrm{~Hz})$. Time-dependent increase of the intensities of the new peaks was observed as the original peak intensities decreased. Furthermore, new singlet signals appeared adjacent ( $6 \mathrm{~Hz}$ higher field) to the gem-proton signals at $\delta 4.04$ (brs: $\mathrm{H} a$ ) and $4.43 \mathrm{ppm}\left(\mathrm{d},{ }^{2} J=1.0 \mathrm{~Hz}: \mathrm{Hb}\right)$, and all of the signals at around 4 to $4.4 \mathrm{ppm}$ were almost entirely lost after $7 \mathrm{~h}$ (Fig. 5d). The change of the gem-proton signal to singlet signals indicated that the geminal spin-spin coupling was cancelled by the independent deuterium exchange at exo-geminal protons. Thus, time-dependent deuterium exchange at exo-methylene protons affected the chemical shifts of the $N$-methyl and 2-methylene groups owing to the isotope effects. After this experiment, the NMR sample $(7 \mathrm{~h})$ exhibited a molecular ion peak at $\mathrm{m} / \mathrm{z} 188$, representing an increase of 2 mass units from $4\left(\mathrm{C}_{12} \mathrm{H}_{14} \mathrm{~N}_{2}\right.$ : mw 186 ), in the EI mass spectrum. Thus, hydrogen-deuterium exchange of the enamine part of $\mathbf{4}$ proceeded smoothly at moderate temperature, compared with that of $\mathbf{3}$, under neutral conditions. A similar result was obtained upon treatment of $\mathbf{4}$ in $50 \%(\mathrm{v} / \mathrm{v}) \mathrm{D}_{2} \mathrm{O} /$ pyridine $-d_{5}$ at $37^{\circ} \mathrm{C}$, while addition of a trace amount of $\mathrm{DCl}$ to a $50 \%(\mathrm{v} / \mathrm{v}) \mathrm{D}_{2} \mathrm{O} / \mathrm{DMSO}-d_{6}$ solution of $\mathbf{4}$ markedly accelerated both deuterium exchange and decomposition. Therefore, the deuterium exchange of 4 might be initiated by addition of $\mathrm{D}_{3} \mathrm{O}^{+}$to the HOMO of the enamine. Based on all of these results, we consider that the deuterium exchange of $\mathbf{3}$ should occur via the enamine form (3exo) generated by means of tautomerism.

Trapping of Enamine Tautomer The frontier orbital (FMO) distributions of $\mathbf{3}$, its enamine form $\mathbf{3 e x o}$, and $\mathbf{4}$ are 


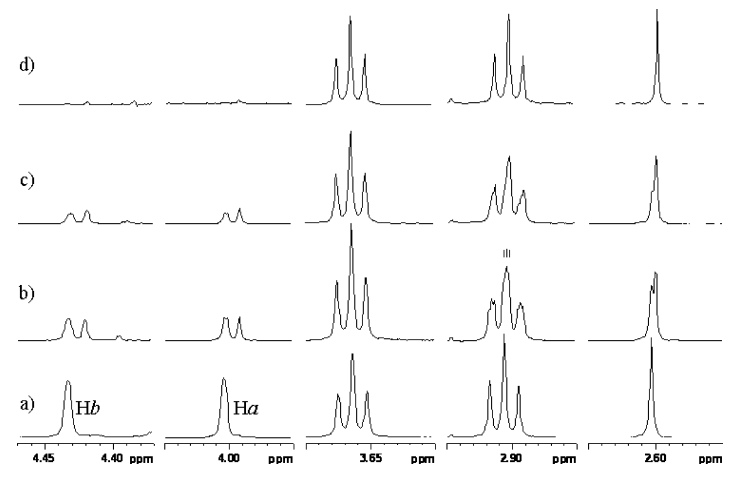

Fig. 5. ${ }^{1} \mathrm{H}-\mathrm{NMR}$ Spectral Change of 4 in $50 \% \mathrm{D}_{2} \mathrm{O} / \mathrm{DMSO}-d_{6}$ at $37^{\circ} \mathrm{C}$ a) Original, and after b) $2.5 \mathrm{~h}$, c) $3.5 \mathrm{~h}, \mathrm{~d}) 7 \mathrm{~h}$.

$$
4 \underset{\text { r.t., } 1 \mathrm{~h}}{\mathrm{Ph}-\mathrm{NCO}}
$$

Chart 4

$$
3 \underset{70^{\circ} \mathrm{C}, 7 \mathrm{~h}}{\stackrel{\mathrm{Ph}-\mathrm{NCO}}{\mathrm{CH}_{3} \mathrm{CN}}}
$$

Chart 5

illustrated in Fig. 6. The FMO of 4 is closely similar to that of 3exo, which is consistent with higher nucleophilic reactivity, compared with 3 . Then, we examined the reaction of 4 with electrophilic phenyl isocyanate (Chart 4).

The reaction in acetonitrile at room temperature reached completion within $1 \mathrm{~h}$ to afford a major product 5 (61\%) with an $m / z$ value of 305 in the EI mass spectrum. The ${ }^{13} \mathrm{C}-\mathrm{NMR}$ spectrum showed only two methylene carbon signals $(2,3$ positions of DHP) and a characteristic quaternary carbon signal at $\delta 78.8 \mathrm{ppm}$ assigned to $\mathrm{C} 4 \mathrm{a}$ by $\mathrm{HMBC}$ spectral analysis, and a carbonyl carbon signal at $\delta 171.9 \mathrm{ppm}$, all of which were consistent with the pyrrolopyrazine structure (Chart 4). Further treatment of $\mathbf{5}$ with phenyl isocyanate gave urea 6 quantitatively.

Treatment of $\mathbf{3}$ with phenyl isocyanate under the same conditions for $3 \mathrm{~d}$ resulted in complete recovery of $\mathbf{3}$. When the reaction mixture was heated at $70^{\circ} \mathrm{C}$, compound 3 reacted with phenyl isocyanate to afford 7 and $\mathbf{8}$ in $28 \%$ and $20 \%$ yield, respectively (Chart 5). The structures of 7 and 8 were determined by NMR analysis including HSQC and HMBC spectra.

The proton signal on the nitrogen $\left(\mathrm{N}_{1}\right)$ atom of 7 was observed at lower field ( $\delta 9.11 \mathrm{ppm})$, compared to that on the other nitrogen atom $\left(\mathrm{N}_{9}, \delta 6.80 \mathrm{ppm}\right)$, suggested that hydrogen bonding between $\mathrm{N}_{1}-\mathrm{H}$ and the 8-carbonyl group contributes to orientation and stabilization of the conjugated anilide part. This effect resulted in the difference in the reaction products. In the reaction of $\mathbf{4}$, there is no stabilization,
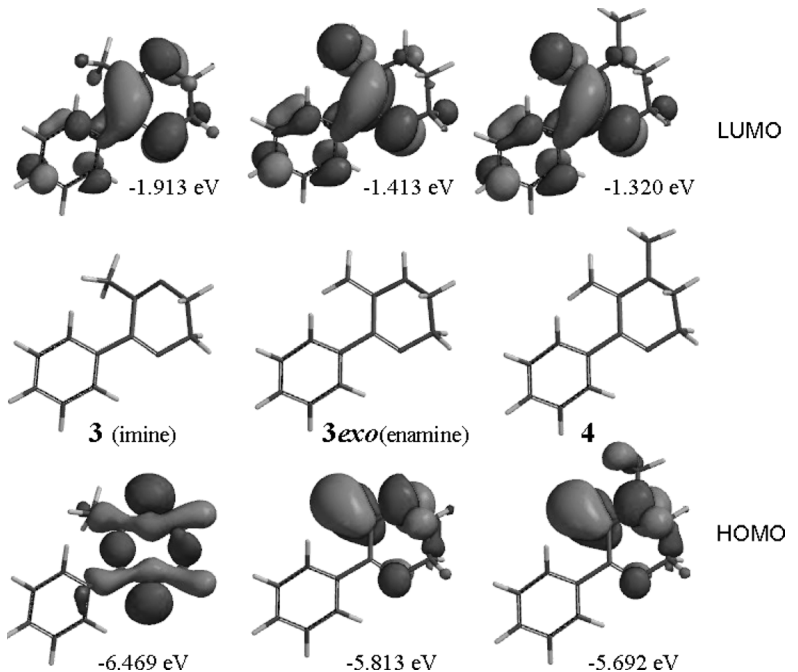

Fig. 6. Optimized Structures (Middle) of 3, 3exo (enamine) and 4, and Their HOMO (Bottom) and LUMO (Top) Distributions with Their Energy Calculated by DFT B3LYP/6-311+G**//B3LYP/6-311+G** Level

such as hydrogen bonding, instead, the existence of the $N$ methyl group is sterically disadvantageous for the formation of Z-olefinic structure, and the E-olefinic intermediate cyclizes to afford 5. Another difference between the reactions of $\mathbf{3}$ and $\mathbf{4}$ is in the reaction position of a second molecule of phenyl isocyanate. In the reaction of $\mathbf{5}$, a second phenyl isocyanate reacts with the secondary amino group $\left(\mathrm{N}_{4}\right.$ position of 13), although the enamine function still remains in 5 , possibly due to the steric hindrance of the $N$-methyl group. On the other hand, the $1: 1$ adduct (7 or an unisolated pyrrolopyrazine-type intermediate) acted as an enamine to afford $\mathbf{8}$ with a quaternary carbon signal at $\delta 77.9 \mathrm{ppm}$ in the ${ }^{13} \mathrm{C}$ NMR spectrum. The ${ }^{1} \mathrm{H}-\mathrm{NMR}$ spectrum of $\mathbf{8}$ showed two broad singlet signals due to $\mathrm{N}_{1}-\mathrm{H}(\delta 8.32 \mathrm{ppm})$ and $\mathrm{N}_{9}-\mathrm{H}(\delta$ $10.09 \mathrm{ppm})$, suggesting hydrogen bonding between $\mathrm{N}_{1}-\mathrm{H}$ and the 8-carbonyl group, and between $\mathrm{N}_{9}-\mathrm{H}$ and the 6-carbonyl group.

Although 3 has potential enamine functionality, it did not react with phenyl isocyanate at room temperature, because methyl-imine character has priority at low temperature. But, upon heating, the tautomerization is activated to generate the latent enamine function. Since the reaction was examined in an aprotic solvent (acetonitrile), a rather higher temperature should be needed, compared with that in the deuterium exchange experiments.

IP of Tautomers A good correlation between the oxidation potential value and the HOMO energy level of the electron donor was reported in photoinduced electron transfer study. ${ }^{24)}$ Therefore, it was suggested that the rise of HOMO energy level, correspond to Koopman's IP, more than $0.68 \mathrm{eV}$ as shown in Fig. 6 by the tautomerism between 3 and 3exo markedly enhanced the electron transfer ability of $\mathbf{3}$ and promoted radical species generation. Actually, the order of the HOMO energy level is $\mathbf{1}(-6.405 \mathrm{eV})>\mathbf{3}$ in DFT B3LYP/6$311+\mathrm{G}^{* *}$ level, whereas, the order of the DNA strand of pBR322 breaking activity was $\mathbf{3}>\mathbf{1}$ same as the order of the HOMO energy level of the enamine form of $\mathbf{3 e x \boldsymbol { c }}>\mathbf{1}$ exo $(-5.889 \mathrm{eV})$. 


\section{Conclusion}

DFT MO calculations indicated preferential imine structure of compounds $\mathbf{1}$ and $\mathbf{3}$. For tautomerization via a simple intramolecular hydrogen shift mechanism, an activation energy of about $270 \mathrm{~kJ} / \mathrm{mol}$ would be required. However, involvement of a water molecule in an intermolecular hydrogen transfer mechanism resulted in a decrease of the calculated activation energy to $160 \mathrm{~kJ} / \mathrm{mol}$. To test the theoretical prediction, deuterium exchange reaction of $\mathbf{3}$ was performed, and temperature-dependent and stepwise deuterium exchange at the 5-methyl group was observed by NMR spectroscopy. The fact that deuterium exchange occurred under mild and neutral conditions indicates involvement of the enamine form 3exo. In addition, we obtained the acyclic and cyclic adducts from the reaction of $\mathbf{3}$ with phenyl isocyanate. The latent secondary enamine character that developed upon heating enhanced the reactivity. These observations are all consistent with tautomerism of 5-methyl-2,3-DHPs. In the physiological environment, polar substances or catalysts might accelerate the enamine formation of 5-alkyl-2,3-DHPs even at physiological temperature. Therefore, the properties of 5-alkyl-2,3-DHPs as enamines might be significant not only in relation to DNA damage, but also in the reactions with peptides, metabolites, and sugars. The significance of the chemical properties of 5-alkyl-2,3-DHPs discussed here in relation to their biological activities ${ }^{25)}$ is under investigation.

Acknowledgements We thank Dr. Hiroshi Masuno for mass analyses.

\section{References and Notes}

1) Kashige N., Yamaguchi T., Mishiro N., Hanazono H., Miake F., Watanabe K., Biol. Pharm. Bull., 18, 653-658 (1995).

2) Yamaguchi T., Kashige N., Matsumoto S., Sato K., Yasuda M., Watanabe, K., Biol. Pharm. Bull., 21, 205-209 (1998).

3) Teixeira P. C., Onuki J., Medeiros, M. H. G., Dornemann D., Di Mas- cio P., Biol. Chem., 382, 913-918 (2001).

4) Ishiguro T., Matsumura M., Yakugaku Zasshi, 78, 229-231 (1958).

5) Yamaguchi T., Kashige N., Mishiro N., Miake F., Watanabe K., Biol. Pharm. Bull., 19, 1261-1265 (1996).

6) Yamaguchi T., Eto M., Harano K., Watanabe E., Kashige N., Harano K., Chem. Pharm. Bull., 44, 1977-1979 (1996).

7) Yamaguchi T., Eto M., Harano K., Kashige N., Watanabe E., Ito S., Tetrahedron, 55, 675-686 (1999).

8) Yamaguchi T., Ito S., Kashige N., Nakahara K., Harano K., Chem. Pharm. Bull., 55, 532-536 (2007).

9) Spartan ' 06 and ' 08 by Wavefunction Inc., Irvine, CA 92612.

10) Lee C., Yang W., Parr R. G., Phys. Rev. B, 37, 785-789 (1998).

11) Marenich A. V., Olson R. M., Kelly C. P., Cramer C. J., Truhlar D. G., J. Chem. Theory Comput., 3, $2011-2033$ (2007).

12) Gollnick K., Koegler S., Maurer D., J. Org. Chem., 57, 229-234 (1992).

13) Barluenga J., Aznar F., Liz R., Cabal M.-P., Synthesis, 1985, 313-314 (1985).

14) Lampe E., Zanocco A. L., Günther G., Piaro N., Tetrahedron, 62, 10734-10746 (2006).

15) Heyns K., Behse E., Francke W., Chem. Ber., 114, 240-245 (1981).

16) Ohta A., Masano S., Iwakura S., Tamura A., Watahiki H., Tsutsui M., Akita Y., Watanabe T., Kurihara T., J. Heterocycl. Chem., 19, 465473 (1982)

17) Bergeron R. J., Hoffman P., J. Org. Chem., 45, 161-163 (1980).

18) Pérez P., Toro-Labbé, Theor. Chem. Acc., 105, 422- 430 (2001).

19) Alagona G., Ghio C., Int. J. Quant. Chem., 108, 1840-1855 (2008).

20) Granik V. G., Pyatin B. M., Persianova I. V., Peresleni E. M., Kostyuchenko N. P., Glushkov R. G., Sheinker Yu. N., Tetrahedron, 26, 4367-4373 (1970).

21) Atta-ur-Rehman, Burney T., Pakistan J. Scientific Industrial Res., 15, 9-10 (1972).

22) CIL NMR Solvent data chart, http://www.isotope.com/cil/products/images/nmrchart.pdf

23) Daly W. H., Underwood J. G., Kao S. C., Tetrahedron Lett., 46, 4375-4378 (1971).

24) Urano Y., Kamiya M., Kanda K., Ueno T., Hirose K., Nagano T., J. Am. Chem. Soc., 127, 4888- 4894 (2005).

25) Takeda O., Takechi S., Ito S., Omori H., Katoh T., Yamaguchi T., Biol. Pharm. Bull., 30, 1663-1667 (2007). 